\title{
POLITICAL REGIME TYPE AND REGIONAL COOPERATION - A CASE STUDY OF ARAB STATES
}

The role and influence of a given type of political regime on regional cooperation has been gaining more and more interest in the study of regionalism in recent years. According to Louise Fawcett and Helene Gandoius, inclusion of a category of types of political regime in the study of regionalism may explain the successes and failures of regional cooperation and fill the cognitive gap in theories of regionalism (Fawcett, Gandois, 2010: 617-636). However, the studies developed so far on the impact of a type of political regime have mainly focused on Africa and Central and East Asia. Moreover, according to Silvia Ferabolli, among all the regionalisms in the world, studies on Arabic regionalism remain the least developed (Ferabolli, 2015: 4). Therefore, the purpose of the article is to show how the type of political system (authoritarian regime) influences the shape of regionalism in the Middle East ${ }^{1}$ and to what extent this political system determines the features of cooperation between Arab states. Taking into consideration the type of political regime in the analysis of regional cooperation allows to supplement the assumptions of the theory of realism, liberalism and constructivism as regards studies on regionalism.

The central argument linking regionalism with a type of political regime is based on the assumption that states that create regional organizations transfer part of their principles, behaviors and mechanisms of action from the state to the international level (Haas, 1961: 366-367). According to this view regional organizations reflect the values and goals that guide their member countries in their internal policies (YassineHamdan, Pearson, 2014: 199). These values and goals result from the type of regime that regulates the functioning of political power and its relations with society.

Based on the above argument, the author puts forward a hypothesis that assumes that a type of political regime is one of the main determinants of regional cooperation. Arab regional cooperation mostly serves to protect and legitimize the political power of authoritarian leaders, playing a very limited role in stabilizing or ordering relations between Arab states. This is evident when member states of Arab regional organizations can not compromise on problematic issues or when they do not prevent disputes and conflicts between member states. Meanwhile European regional organizations fulfills the function of stabilizing, ordering and dynamizing relations between states, as well as a coercive function when necessary. The latter function in the case of Arab regional organizations conflicts with the principle of protecting the sovereignty and re-

${ }^{1}$ Regionalism in the Middle East is limited only to the Arab states bypassing three regional powers: Israel, Iran and Turkey. 
gimes of Arab states, which they regard as one of the most important. Regional organizations of authoritarian states tend to drive down democratic ambitions and maintain the authoritarian status quo.

In order to verify this hypothesis, the following research questions were posed. First, how is the type of political system related to regional cooperation? Second, can autocracies work effectively together? To verify the hypothesis and answer the research questions, the author refers to the theory of realism, constructivism, neo-functionalism and the typology of political systems to show that there is no single theory that could fully explain processes in international relations.

\section{REGIONALISM IN THE MIDDLE EAST THROUGH THE PRISM OF INTERNATIONAL RELATIONS}

There are two most common approaches to studying Arab regionalism in the Middle East which are constructivism and realism. Beside these two approaches, there are often a reference to the assumptions of liberalism (democracy, economic interdependence, institutionalization) and neo-functionalism (the mechanism of a transfer in domestic allegiances) because they shows what conditions of regional cooperation Arab regional organizations do not meet. Since there is no single theory that fully explains the phenomena and processes occurring in international relations, I will use the assumptions of each of them to explain regionalism in the Middle East.

The first approach is based on the school of constructivism and implies that, despite many failures in the integration of the region, the Arab states have built a supranational community that shares common values, beliefs or attitudes. These assumptions explain the official motives behind the establishment of the League of Arab States (LAS) and, to a certain degree, the Gulf Cooperation Council (GCC). Pan-Arabism was perceived by founding states of LAS (Saudi Arabia, Egypt, Iraq, Yemen, Jordan, Lebanon, Syria) as an ideology that was to lead to the integration of the Arab world. In turn, in the case of the GCC, the Khaleeji identity, based on a common religion, language, culture, and similar legal, economic, political and social conditions, was to play such a role.

Michael Barnett, a representative of the school of constructivism, believes that the Arab world creates a specific supranational community that shares the belief that it is connected by shared ties and constitutes a separate community: the Arab nation. It accepts certain norms and rules of conduct that must be followed to be included in the Arab community, and Arab leaders are more likely to fight with each other in the symbolic sphere than by using military means ${ }^{2}$. Barnett also distinguishes three common fears and focuses of the Arab community: 1) attitude towards the West, 2) attitude to Zionism and Israel, and solidarity with the Palestinian people 3) how to reconcile Arab unity with sovereignty? (Barnett, 1998: 10-11, 25-27).

${ }^{2}$ Contrary to appearances, wars between Arab states are not common in the Middle East. The MENA region has experienced 8 wars between countries, of which only 1 was waged between Arab states: the First Gulf War between Iraq and Kuwait. In the other seven wars, an Arab state stood on one side, and a non-Arab state on the other, such as Iran, Israel, the United States, Great Britain or France. F. Gaub, Arab wars: calculating the costs, "Brief EU" 2017, No. 25, pp. 1-7. 
Despite many failures in the pursuit of unification of the region, many regional projects and initiatives have arisen that are worth taking a closer look at. Morten Valbjørn says that in less sensitive areas such as education and cultural cooperation, Arab countries have drawn near to each other. The presence of regional Arab organizations has contributed to a restoration of a sense of "Arabness" and a degree of commonality of interest (Valbjørn, 2016: 342). This means that Arab countries have a potential that can be used for political and economic integration, supported by institutions such as the Gulf Cooperation Council or the Greater Arab Free Trade Area (GAFTA). The development of specialization in individual Arab countries may also provide such a potential, which may lead to comparative advantage. For example, Egypt and Jordan specialize in the low cost of food and chemical production, Morocco - in the production of food and agricultural products and the United Arab Emirates in vehicles and machinery.

However, if we quote the definition of integration by Ernst Haas, a representative of neo-functionalism, it soon turns out that there is no integration in the Middle East. According to this approach, integration is a process that forces state entities to transfer loyalty, expectations and political activity to a supranational level, and as a result to create a new community (Haas, 1961: 367-368). Referring these assumptions to the Middle East we can recognize that not only loyalty, but also political expectations and actions are not transferred by authoritarian states to the level of regional organizations. Institutionalization that is closely interlinked with integration should support development and cooperation between states, eliminate distrust, create states' commitments to common norms and values, and promote political transparency. However, in the Middle East, regional institutions are weak and ineffective because they do not have sufficient powers that are maintained by the authoritarian leaders of their member states. An example of such an institution is the Peninsula Shield Forces (military arm of the GCC), whose development and operational capabilities are limited by the leaders' fear of creating too strong army, which in many Arab countries in the past was responsible for the coup d'état.

According to many researchers, regionalism in the Middle East is meaningless. Paul Aarts describe the Middle East as the "black hole on the world map of regionalism" (Aarts, 1999: 911-925), Alexander Bellamy called processes occuring in the region as "a stalled integration" (Bellamy, 2004: 118-149), while Matteo Legrenzi claims that progress in regionalism processes is limited (Legrenzi, 2013: 1-10). Such opinions often lead to the conclusion that there is no point in finding regionalism if it is ineffective. On the other hand, there is a growing literature on regionalism in the Middle East that explore its features and the causes of its failures. Why? Because unsuccessful attempts at regional integration in the Middle East provide an opportunity to analyze factors adverse to integration and identify the obstacles to this process. It also helps to create a more complete picture of regionalism, because this phenomenon occurs not only in Europe, but also in the Third World.

In fact, regionalism in the Middle East has failed to "lift" borders or introduce the free movement of people, capital and services. Internal trade is at a very low level and regional institutions are ineffective. The purpose of the League of Arab States was to strengthen close relations and numerous ties, and to care for the welfare of all Arab 
states but it has failed. The Arab Cold War (the rivalry between nationalist and traditionalist states in 1952-1970) or the Arab Spring (the revolutions against oppressive regimes and a low standard of living since 2010) are good examples showing the lack of action of regional Arab organizations that led to the region's explosion and ineffectiveness in crisis management in these turbulent times (Dziekan, Zdulski, Bania, 2020: 105). Unless it was keeping the authoritarian leaders in power and the use of the LAS by Egypt for its particular interests (e.g. Egypt's interference in Lebanon's political affairs in 1958 and Gamal Abdel Nasser's sabotage of the LAS response to the Beirut authorities' complaint) that were the organization's goals (Lipa, 2016). If so, it would show that the LAS was designed for purposes different than, for example, the European Union (EU). Michael Barnett and Etel Solingen even argue that the League of Arab States was designed to fail because its leaders when establishing the organization sought weak regional institutions that couldn't produce any deep collaboration and integration that could weaken the political leaders at home. One of the reasons for this perception of regional cooperation by Arab states was the fact that they were just beginning to gain independence, so the discussion about some kind of unity led them to fear that this could undermine their newly-acquired political authority. In that sense authoritarian leaders were primarily concerned with domestic regime survival (Barnett, Solingen, 2007: 181).

A different approach to regional cooperation is presented by the theory of realism (or, interchangeably, neo-functionalism) and assumes that cooperation between states is absent or very limited, because international relations are dominated by conflict and competition. If there is any cooperation between states, it is motivated by the state's own interest (power, security, domination), not the interest of the region.

Realism revolves around four main proposals: 1) states are the central actors in international politics, rather than leaders or international organizations; 2) the international political system is anarchic, as there is no supranational authority to enforce rules; 3) states act in their rational self-interest within the international system 4) states desire power to ensure self-preservation (Goodin, 2010: 133). These ideas emphasize the selfish interests of states (power, security, sovereignty), which, even if they cooperate, do so for their own purposes. Such goals of authoritarian regimes result from the unstable environment of the Middle East and limited trust to other states. The influence of third and non-Arab countries or the newly-created (fragile) Arab states can already be treated as a sufficient reason to secure and strengthen their own power, e.g. by establishing and participating in a regional organization (bandwagon). This last case concerned especially small countries exposed to threats from neighbors, for example Kuwait, which a few weeks after independence (June 19, 1961) joined the LAS (July 20, 1961), fearing the threat of Iraq.

Another theory useful in the analysis of regional cooperation is neorealism, which includes concepts useful in explaining cooperation in the Middle East. Stephen Walt perceives cooperation in the region in a similar way to alliances (formal or informal associations aimed at cooperation in the field of security between states), which strengthen the potential and defense capabilities of a regional organization and its members (Walt, 1999: 1). This is the case of the GCC which was perceived as an instrument for the survival of the monarchical regimes. The organization was 
established in response to the threat from Iran, which after the 1979 revolution began to manifest regional power aspirations and interfere in the internal affairs of Arab states (proxy wars). However, after several years there was a split within the organization. Some countries were in favor of greater openness to dialogue with Iran (Qatar, Oman, Kuwait), while other countries promoted a more offensive approach (Saudi Arabia, United Arab Emirates, Bahrain). This broke the unity in the GCC and contributed to deep crises in 2014 and 2017. Security ceased to play an integrative role between the Arab Gulf States.

Arab regional organizations often failed to achieve the goals declared in their founding agreements, but this did not prevent their member states from consolidating and strengthening regimes. The above exposes the divergences between the theoretical assumptions contained in the treaties and their implementation. It also emphasizes two assumptions: 1) that the main actors of international relations are states, not international organizations 2) that one of the main motives of states' actions is to increase their strength and security (Thompson, 1960). This happens when authoritarian regional organizations strengthen the status quo in the region, creating a protective umbrella over the sovereignty of authoritarian states and protecting against third countries' interference in their internal affairs. An example illustrating the policy of Arab regional and subregional organizations aimed at securing and strengthening an authoritarian regime is the intervention of the armed forces of the Peninsula Shield Forces (the military arm of the Gulf Cooperation Council) during the events of the Arab Spring in Bahrain in 2011 and the support given by the League of Arab States for this intervention. The spiritus movens of this intervention was Saudi Arabia, which first wanted to prevent the potential liberalization of a neighboring state, and secondly accused Iran of inciting an uprising by warning other Sunni states against the Tehran regime. Armed intervention not only helped quickly stabilize the situation in Bahrain, but also strengthened Saudi Arabia and the milieu of like-minded and similarly-acting states. The intervention also showed potential opposition movements that any anti-government actions would be met with firm resistance from the rulers. In turn, the League of Arab States expressed its opposition to the Iranian state's involvement in Arab internal affairs. The LAS also sent a letter to the Iranian Ministry of Foreign Affairs emphasizing that the Persian state should respect Bahrain's independence. The strategy to ensure the security of the authoritarian regime by a regional organization is known as "regime boosting." Fredrik Söderbaum described this mechanism on the example of African regional organizations: "Many ruling (or crumbling) regimes and political leaders in Africa engage in symbolic and discursive activities, whereby they praise the goals of regionalism and regional organizations, sign cooperation treaties and agreements, and take part in 'summitry regionalism,' but without having a commitment to or bearing the costs of policy implementation" (Söderbaum, 2010).

However, while realism, neo-realism, neo-functionalism and constructivism contribute much to understanding regional cooperation in the Middle East, they do not consider the impact of a type of political regime on this cooperation. According to Alexander Libman and Anastassia Obydenkowa, regional organizations can be divided, based on the type of political regime, into democratic regional organizations (DROs) and undemocratic regional organizations (NDROs) (Libman, Obydenkova, 2019: 
3-9). According to them, the different goals and mechanisms of regional organizations in Europe and Asia result from different types of political regimes.

The biggest contribution of Libman and Obydenkova to the division into DROs and NDROs in the analysis of Arab regional organizations is a change in the perception of their goals, functions and strategies. For a long time, many Middle East researchers believed that the LAS or GCC did not meet the goals and functions assigned to regional organizations: regulating relations between states, stabilizing them, ordering the regional environment, coercion when a state violates the established rules etc. However, the LAS and GCC dealt with them to some extent, because the dominant functions of these organizations were the consolidation of regime power, the principle of non-interference of the regional organization in the internal affairs of the member states (which would be contrary to the function of coercion) or the patrimonial function (using regional organizations to pursue their own interests). So what are the basic differences between a DRO and NDRO?

DROs are used to support democratization processes in the region by creating incentives for democratic reforms, offering membership and assistance or threatening undemocratic members with financial penalties, sanctions or expulsion. These instruments are used when states break the democratic commitments that they had promised to keep like separation of powers. Before accession to the EU, candidate states must meet certain political and economic conditions known as convergence criteria. Therefore, the standards of DRO countries are more uniform because only states that meet specific requirements are invited to the organization. After the accession of the new countries to the EU, actions are taken to equalize the level of economic development and infrastructure between "old" and "new" Member States to reduce the differences between them. In addition, DROs must take into account the preferences of their own citizens (e.g. EU referenda, elections), which are usually overlooked in authoritarian states. Meanwhile, an NDRO primarily serves as an instrument of legitimization of authoritarian rules in members states, such as in the League of Arab States. Such organizations provide an international structure that helps maintain the political status quo and keep authoritarian leaders in power. Article 8 of the Pact of the League of Arab States says: "Every member State of the League shall respect the form of government obtaining in the other States of the League, and shall recognize the form of government obtaining as one of the rights of those States, and shall pledge itself not to take any action tending to change that form." This provision means that the internal policies of the member states remain outside the jurisdiction of the organization and confirms the principle of supremacy of states in international relations (the anarchy of the international system). Another mode of action aimed at securing regimes by NDROs is to create an international environment that reduces political threats (democratization, liberalization) to their survival. The Arab Spring has shown that authoritarian regimes, apart from Libya, Syria, Egypt and Yemen, have remained immune to the wave of anti-government protests. The limited reactions of the LAS and GCC have allowed the political status quo to be maintained without allowing any liberalization of political systems. The countries that played a key role during the LAS and GCC interventions in Libya, Yemen and Syria, i.e. Saudi Arabia and Qatar, strengthened their position in the region. 
Furthermore, the organizational commitments of the DRO and NDRO member states are dissimilar. In the LAS Charter there are listed numerous ambitious aims that include "The recourse to force for the settlement of disputes between two or more member States shall not be allowed" or "The Council shall mediate in a dispute which may lead to war between two member States or between a member State and another State in order to conciliate them" or in case of aggression or threat of aggression by a State against a member State "the Council shall determine the necessary measures to repel this aggression [...] and its decision shall be taken unanimously" (Pakt Ligi Państw Arabskich, 1945: 47-59). Meanwhile the LAS didn't prevent disputes between member states (Iraq-Kuwait war 1990, border disputes in the Persian Gulf), only some of the conflicts were successfully resolved by the LAS, and the organization stayed inactive during most of the armed conflicts in the Arab World. Such inaction resulted, inter alia, from the above provisions, which assumed not to interfere in the internal affairs of other countries, although in relations at the state level the proxy wars amount to such an intervention. Moreover, authoritarian regimes create an impression that they tend to take care about the interests of their citizens. The preamble of the LAS Charter states that the organization was established, among others, "[...] in order to direct their efforts toward[s] the goal of the welfare of all the Arab States, their common wealth, the guarantee of their future and the realization of their aspirations [...] and in response to Arab public opinion in all the Arab countries." Through such a provision the authoritarian leaders create an impression that the LAS serves the development and stability of the region.

NDROs were also established to delegitimize the 'other,' i.e. the West (LAS's opposition to the US attack on Iraq in 2003), Shiite Iran (to support of the LAS for the Saudi coalition against the Houthi armed movement in Yemeni Civil War 2015-), Israel (boycott by the LAS of Israel and countries cooperating with Israel, such as Egypt, whose membership was suspended for 10 years in retaliation to the peace treaty between Egypt and Israel in 1979) or the creation of alternative norms and values such as the identity of the Khaleeji (an identity associated with the Arab Gulf States) (Russo, Stoddard, 2018: 2-5). An NDRO provides material support, which is used by authoritarian elites, such as the LAS loan to Egypt in 2017, to compensate for the decline in tourism in that country or the LAS loan to Yemen to support economic restructuring programs. Both loans came from the Arab Monetary Fund which is a suborganization of the LAS. Both loans supported autocrats: Gen. Abd al-Fattah as-Sisi and Ali Abd Allah Salih.

NDROs use governance mechanisms and informal interaction (policies based on circumventing the law or finding legal loopholes to solve problems not provided for by law or the tasks of formal institutions) to govern rather than relying on bureaucratic institutions. Because NDROs do not have elected institutions, the key role in the decision making process is played by autocrats. They take decisions in the name of the organization. NDROs are also more heterogeneous (in power distribution, economic development, military capabilities) than DROs. In the LAS there are rich and poor countries with GDPs ranging from $\$ 683$ billion in Saudi Arabia and Yemen with $\$ 18$ billion. In OPEC we can find Arab, African and American cultures. Finding a consensus in such organizations is more difficult but from the point of view of NDRO goals, this does not seem to be the most important matter (Obydenkova, Libman, 2019: 9). 
Summarizing the above argument we can try to answer the question: why are authoritarian regimes involved in regional cooperation? Authoritarian states engage into regional cooperation to maintain regime stabilization and its survival. An authoritarian regime builds close economic or political ties with states in its close proximity to secure their allegiance to foster its own standing. It tends to create a friendly environment that will reduce democratic ambitions in its own country and create a space for communication that will contain liberal ideas and reduce external critique. Constructivist arguments refer to legitimacy concerns and identity-based motives. An RO can be used to stabilize a domestic regime but also as a tool for antagonizing the Western liberal-democratic model by proposing an alternative identity based on historic or religious sources and ties (Kneuer, Demmelhuber, Peresson, 2018: 5-7).

\section{THE INFLUENCE OF AUTHORITARIAN REGIME ON REGIONAL COOPERATION}

According to the Freedom House reports the Middle East is the most authoritarian region in the world (Brynen, Moore, Salloukh, Zahar, 2014: 4). The authoritarian form of governance influences the shape of regional cooperation, and many assumptions of the school of realism will apply to its analysis. Realism explains the nature of the authoritarian political system because of its specific features.

Authoritarian regimes usually do not trust other states, which leads them to mutual tensions and limited cooperation; they refuse to hand over state prerogatives to regional institutions (at least in the Arab world); they often apply a hard power policy and invest heavily in security; put the interests of the nation-state above regional interests; in these countries there is no or very limited civil society, although it plays a crucial role in integration processes; they do not like compromises with local constituencies, but are also not willing to compromise with neighboring countries at the level of regional organizations. An important component of authoritarian system are limited access orders (LAO) (North, Wallis, Wingast, Webb, 2013) which means that in these regimes the core political positions and economic resources are restricted by the state leadership to a relatively small group of the elite. These restrictions provide benefits only for the regime leaders and their supporters who produce allowances that are distributed to gain the support of powerful elites and ensure domestic stability. All these features of authoritarian regimes remain a crucial obstacle on the road to regional cooperation, which makes the process of region building in the Middle East difficult to achieve.

Among the many features of an authoritarian system, sovereignty occupies important place in the political program of these countries. Sovereignty is an absolute priority for autocrats and is linked to national identity, political power, political control and maintaining the status quo. There is usually no political opposition in authoritarian states (or it is very limited) and its leaders do not share power with it. Leaders who are not ready for a more pluralist system or being a subject of parliamentary scrutiny are not ready to share power internationally with regional organizations. Arab political leaders fear that structures of regional cooperation could be used as an instrument of international intervention into their state affairs (Tripp, 1996: 304). That is why there 
is a lack of international interventions (with a few exceptions like GCC intervention in Bahrain 2014) carried out by regional organizations in the Arab world.

In addition to the separation of powers, authoritarian states also reject democratic principles such as good governance. Principles such as constitutions, human rights, NGOs, political parties and government, exist in nominal sense but they have little influence on major political decisions and foreign policy that remain under Arab leaders' control. From that point of view these institutions can be called "virtual" because they do not provide a transfer of power from top to bottom. The priority is regime security and to maintain the incumbent rulers in power (Allison, 2008: 186-190).

The above features of authoritarian states make it difficult for them to cooperate in regional arenas. The more authoritarian and conservative the state is, the less it is inclined to cooperate within regional projects. We can see this on the example of Saudi Arabia at the GCC, where Qatar's policy, contrary to the interests of the Kingdom, led to the imposition of sanctions and a diplomatic crisis in 2017.

Realism provides a significant contribution to understand the nature of authoritarian regimes. According to this approach authoritarian states use violence in order to sustain their rule and protect themselves against external threats. The purpose of such behavior is regime stability which becomes the main incentive for the building of regional organizations. Exclusion of citizens from state power structures and the militarization of regimes based on violence as a means to ensure the regimes' survival leads to the increase of security mechanisms and apparatus of Arab states. Such a policy of authoritarian states impedes the overall development of Arab states (Ayoob, 1996: 5-23).

Realists treat authoritarian regimes as security regimes under imminent threats to their rule. According to Kathleen Collins, authoritarianism is the main reason behind failing regionalism because authoritarian states are less inclined to cooperate within binding regional arrangements. Authoritarian leaders are interested only in their survival so they will only support activities that strengthen their authority. An example of ensuring the regime's security is the inclusion of the casus foederis principle in the GCC and LAS treaties, although it has never been applied. They speak about their commitments to deepen cooperation with other states and to elements of democracy like elections but this is only a virtual form of regionalism. As regards that assumption, regional security will be one of the most important areas of cooperation among authoritarian regimes especially when it bolsters their rule (Collins, 2009: 249-281).

Accordingly, Roy Allison uses the term "protective integration." Authoritarian states use regional organizations to strengthen political solidarity in the face of external pressures or threats that could threaten their power. This form of solidarity will not develop into deeper cooperation as long as regional security remains competitive, which leads authoritarian states to consolidate national identities and apply nationalist rhetoric (Allison, 2008: 185-202).

When authoritarian leaders focus on national sovereignty and regional conflicts in the absence of complementary trade relations, then building regional institutions is much more difficult. Barry Buzan (Copenhagen School) argues that authoritarian states' commitment to a virtual form of regionalism creates "protective integration" and unites them in resistance against external pressures for regime change (Buzan, Waever, 2003: 
423-429). The GCC was supposed to be such a protective shield against the threat from Iran. Its members were afraid of Iran's control over the Shi' ite minorities in the Sunni oil monarchies and interfering in internal affairs. In addition, Iran's broad influence in Iraq and Yemen is portrayed, especially by Saudi Arabia, as a threat to the security of the Sunni oil monarchies. However, not all GCC countries share this subjective perception of threat. It is not possible to succeed in developing a collective security strategy when there is no common threat perception or coordinated policies. A common enemy not only gives states a basis for cooperation, but also helps strengthen their power in the face of security threat and strengthen their legitimacy. This proves that authoritarian regional organizations reinforce autocracy in the name of promoting security in the region (Bohr, 2004: 498-501). However, the priority of security issues hampers economic development and, as a result, regional economic cooperation. This situation occurs, to a greater or lesser extent, both in the case of GCC and LAS.

\section{SELECTED EXTERNAL DETERMINANTS OF MIDDLE EAST REGIONAL COOPERATION}

In the context of the hypothesis on the impact of the type of political regime on regional cooperation in the Middle East, it is worth at least briefly discussing other variables that affect the effectiveness/inefficiency of Arab regional organizations. The main theories of international relations, constructivism, realism and liberalism are useful in analyzing these variables. In constructivism, identity has a central place, which affects the motivations and behavior of actors in international relations. However, a common Arab identity (pan-Arabism) was not enough for institutionalization and cooperation in the region to be effective. Arabism was responsible for both cooperation and conflict, and in such conditions it was difficult to build a coherent region. Arabism attracted states toward each other and pulled them apart. The former can be illustrated by the creation of the LAS in 1945, while the latter can be seen in the power struggle between Iraq and Syria. The 1966 coup split the Ba'ath Party between the Iraqi-dominated Ba'ath movement and the Syrian-dominated Ba'ath movement. When looking for other sources of ineffective regional cooperation in the Arab world, it's worth referring to the categories specific to realism (like the distribution of power and interference of a great power) and liberalism (such as economic diversification). Thus, political homogeneity and economic diversification are favorable conditions for regional cooperation.

The distribution of power in the region is important factor affecting the efficiency of regional organizations. The struggle for power and domination in the region between the aforementioned Iraq and Syria, Egypt and Saudi Arabia (which led to the so called "Arab cold war" between nationalist and conservative Arab states 1952-1979) and even between Saudi Arabia and Iran diminish regional cooperation (since 1979). The Arab League could not prevent these conflicts, and there are only a few successful interventions in its history. ${ }^{3}$ As regards the Saudi Arabia-Iran proxy wars, although

${ }^{3}$ Successful LAS interventions include: the Iraq-Kuwait crisis 1961, Algerian attack on Morocco 1963, conflict between Northern and Southern Yemen 1979, Civil War in Lebanon 1975-90. 
Iran does not participate in the processes of Arab regional cooperation, this does not mean that it does not affect relations between Arab states. Iran conducts a superpower policy in the region, involving Arab states in proxy wars (Iraq, Lebanon, Yemen, Syria) and creating a security dilemma in relations with them. Iran's influence on the relations between Arab states is particularly visible in the case of the GCC. The GCC was established in 1981 as a reaction to the Iranian revolution and the view that the idea of exporting the revolution was a common threat to the Sunni monarchies of the Persian Gulf. From this perspective, the establishment of the GCC can be seen as a part of the neo-realism theory, which assumes that states form alliances to obtain instruments to ensure their security (Walt, 1999: 1). However, since the 1990s, some GCC countries, especially Qatar and Oman, have begun to pursue an open policy towards Iran. Qatar's policy towards Iran was determined by geoeconomic considerations, i.e. shared exploitation of the North Field/South Dome gas field while Oman policy toward Iran was determined geopolitical considerations which was common supervision of the Strait of Hormuz. Under the agreement signed in September 2013 between Oman and Iran, both countries conduct joint navy exercises.

There was (and still is) a lack of complementarity that would bind the countries economically and orient them towards each other. The low interdependence and complementarity of the Arab economies translates into weak trade in the region and competition in the same markets. The Arab states of the Persian Gulf are countries with particularly low economic complementarity and poor trade relations. The main export commodity of these countries is oil, which for years has contributed to the neglect of other sectors of the economy and industry. As a result, consumer and industrial goods that cannot be locally produced are imported, linking Arab Gulf States with countries outside the region. Therefore, economic diversification efforts remain an important milestone on the way to economic integration. Despite many economic agreements concluded under the GCC, the level of intra-regional trade remains at dramatically low at $8 \%$. The Arab states of the Persian Gulf have undertaken national programs to diversify their own economies. Therefore, economic diversification efforts are mainly state initiatives, so the GCC plays a minor role in this process.

Another important factor affecting integration processes in the Arab world is the interference of great powers (USA, France, Great Britain, Russia) in the internal affairs of the countries of the region. According to some Middle Eastern researchers (Harrison, 2018: 11), this is the most penetrated region in the world by foreign powers (e.g. the American policy of "twin pillars" in the Middle East in the 1970s, or the Carter Doctrine of a close US alliance with Saudi Arabia against Iran from the 1980s). The alliances of Arab states with Western powers lead to accusations of collaboration with the enemy (e.g. the cooperation of Saudi Arabia with the USA) and are used to delegitimize pro-American regimes. In consequence, they build distrust between Arab states and make them dependent on the help of foreign powers.

An important obstacle to regional cooperation remains the lack of one regionally recognized leader - a state, that could play a key role in subsidizing the costs of cooperation. Such a role could be played by Saudi Arabia or Egypt, but it subordinated regional cooperation to its own national interests and treated it as a competitive regime survival policy. Common Arab sovereignty and nationalism, combined with a dis- 
course on Arab unity, have been used to legitimize authoritarian regimes. Therefore, it can be argued that a weak and ineffective LAS arose as a result of the fear of Arab leaders about the loss of their sovereignty and power, as coups and changes in the ruling elite occurred quite often in the Arab world. The survival of the regime gained priority over strong regional institutions in the foreign policies of Arab states.

This does not means that Arab leaders don't want to be associated with regional aspirations and work toward wealth and peace. Political leaders realized that showing readiness to integrate regionally and all outcomes associated with such integration could give them popular support. Just like the Arab identity was used to reinforce Arab regimes. The nationalization of oil, the Suez canal and other industries led to the rise of rentier states which became a source of political support. The lion's share of these gains were received by the security sector in the form of investments and benefits (Richards, Waterbury, 1990: 362). However, in spite of the large military contingents in Arab states, the LAS has no military force of its own (except a peacekeeping force) whereas even the democratic EU has such a contingent. The member states of the LAS have some institutions to show their commitment to prosperity and unity but not enough to override state sovereignty and domestic political power.

So what did the LAS achieve? Under the LAS, Arab countries have developed close cooperation on non-political issues like health, economic, financial, social and cultural matters, putting political concerns aside. Such a political issue could be, for example, the desire of member states to create a single Arab state (federation), but there is no such provision in the LAS Charter. Foreign policy and a joint defense system were excluded from the Charter so the cooperation was (is) barely functional (avoidance of political affairs). Involvement in political affairs was significantly limited by the securing of state sovereignty. It seems that the founding of the organization was to cement the political status quo.

The power and sovereignty of both member states and regional organizations occupy an important place in regional cooperation. In the case of authoritarian states, we are dealing with systems with limited access, which means that the main political positions and access to the state's economic resources are reserved exclusively for the authorities and a small group closely associated with them. The beneficiaries of such cooperation are primarily the "political elites" and their allies. They play managerial roles in regional organizations. Thus, the type of political regime influences the form of regional cooperation, which will be based on other mechanisms and have different goals in the case of democratic and undemocratic countries (North, Wallis, Webb, Weingast, 2013).

Based on the LAS and GCC case studies we may conclude that ROs designated by authoritarian states have a barely symbolic and instrumental character and are aimed rather on domestic politics than regional cooperation. The survival of the ruling regimes was a pivotal consideration in the LAS (Tripp, 1995: 283-308). Arab leaders were not and still are not ready to sacrifice their individual interests in favor of regional integration. In the last half of the century, political leaders were more focused 
on state building projects and survival strategies than on political cooperation on the regional level. The low institutionalization of the LAS underscored the greater importance of the authoritarian leaders. In 1980s, the LAS passed over 4000 resolutions of which $80 \%$ were never implemented. Resolutions that were passed by unanimous vote (Salame, 1988: 276).

On the other hand, the low diversification among the GCC countries weakened their interdependence. Lack of confidence in Saudi Arabia's policies and goals, primarily from Qatar and Oman, as well as their different attitude towards Iran, contributed to the organization's breakup into two factions. The GCC did not prevent a serious SaudiQatar crisis because the leaders of these countries decide on the functionality of the organization. Therefore, if there is no good will between those in power, the role of an organization in mutual relations is secondary.

This case studies clearly shows that the logic of regime survival prevailed and domestic regimes imposed important barriers on collaboration making it more difficult to attain. This made the LAS and GCC to play a meaningless role in preventing conflicts in the region. Such an inaction led Amr Moussa, the Arab League Secretary-General, to the conclusion that the League could be replaced by a new system, like the UN replaced the League of Nations (Barnett, Solingen, 2007: 215). However, as long as the LAS and GCC reactivation will not be in the interests of the states, it will never happen.

\section{REFERENCES}

Aarts P. (1999), The Middle East: a region without regionalism or the end of exceptionalism?, "Third World Quarterly", Vol. 20, No. 5.

Allison R. (2008), Virtual Regionalism, Regional Structures, and Regime Security in Central Asia, "Central Asian Survey", Vol. 27, No. 2.

Ayoob M. (1996), The Third World Security Predicament: State Making, Regional Conflict, and the International System, Boulder.

Barnett M. (1998), Dialogues in Arab Politics: Negotiations in Regional Order. A Narrative of Arab Politics Which Dialogues Among Which Arab States, New York.

Barnett M., Solingen E. (2007), Designed to fail or failure of design? The origins and legacy of the Arab League, in: Crafting cooperation: regional international institutions in comparative perspective, (eds.) A. Acharya, Al. Johnston, New York-Cambridge.

Bellamy A. (2004), Stalled integration and perpetual war: The Gulf Cooperation Council, in: Security Communities and their Neighbours Regional Fortresses or Global Integrators?, (eds.) A. Bellamy, New York.

Bohr A. (2004), Regionalism in Central Asia: New Geopolitics, Old Regional Order, "International Affairs", Vol. 80, No. 3.

Brynen R., Moore P., Salloukh B. F., Zahar M. (2013), New Horizons in Arab Politics, in: Beyond the Arab Spring: Authoritarianism and Democratization in the Arab World, (eds.) R. Brynen, P. Moore, B. F. Salloukh, M. Zahar, New York.

Buzan B., Waever O. (2003), Regions and Powers: The Structure of International Security, Cambridge. 
Collins K. (2009), Economic and Security Regionalism among Patrimonial Authoritarian Regimes: The Case of Central Asia, "Europe-Asia Studies", Vol. 61, No. 2.

Dziekan M., Zdulski K., Bania R. (2020), Arabska wiosna i świat arabski u progu XXI wieku, Łódź.

Fawcett L., Gandois H. J. (2010), Regionalism in Africa and the Middle East: Implications for EU Studies, „Journal of European Integration”, Vol. 32, No. 6.

Ferabolli S. (2015), Arab regionalism. A post-structural perspective, New York.

Goodin R. (2010), The Oxford Handbook of International Relations, Oxford.

Haas E. (1961), International integration: The European and the Universal Process, "International Organization", Vol. 15, No. 3.

Harrison R. (2018), Regionalism in the Middle East: an impossible dream?, „Orient”, No. 59. Vol. 1.

Kneuer M., Demmelhuber T., Peresson R., Zumbragel T. (2018), Playing the regional card: why and how authoritarian gravity centers exploit regional organizations, "Third World Quarterly", Vol. 40, No. 3.

Legrenzi M. (2013), Regionalism and regionalization in the Middle East: options and challenges, International Peace Institute.

Lipa M. (2016), Autorytaryzm i liberalizacja gospodarcza w Egipcie, Warszawa.

North D. C., Wallis J. J., Webb S. B., Weingast B. R. (2007), Limited Access Orders in the Developing World: A New Approach to the Problems of Development, World Bank Policy Research Working Paper Series 4259.

Obydenkova A., Libman A. (2019), Authoritarian Regionalism in the World of International Organizations. Global perspectives \& the Euroasian enigma, Oxford.

Pakt Ligi Państw Arabskich (1945), in: Zbiór dokumentów (1946), (ed.) J. Makowski, No. 2, tome 5, s. 47-59.

Richards A., Waterbury J. (1990), A Political Economy of the Middle East - State, Class, and Economic Development, Boulder.

Russo A., Stoddard E. (2018), Why do Authoritarian Leaders do Regionalism? Ontological Security and Eurasian Regional Cooperation, "The International Spectator", Vol. 53, No. 3.

Salame G. (1988), Inter-Arab Politics: The Return to Geography, in: The Middle East: Ten Years After Camp David, (ed.) W. Quandt, Washington.

Söderbaum F. (2010), With a Little Help From My Friends: How Regional Organizations in Africa Sustain Clientelism, Corruption and Discrimination, http://www.pol.gu.se/digitalAssets/1316/1316597_soderbaum.panel1.pdf.

Thompson K.W. (1960), Political realism and the crisis of world politics, Princeton.

Tripp C. (1995), Regional Organizations in the Arab Middle East, in: Regionalism in World Politics: Regional Organization and International Order (eds.) L. Fawcett, A. Hurrell, New York.

Valbjørn M. (2016), North Africa and the Middle East, in: The Oxford Handbook of Comparative Regionalism, (eds.) T. Börzel, T.Risse, Oxford.

Walt S. M. (1999), The origins of alliances, New York.

Yassine-Hamdan N., Pearson F. S. (2014), Arab approaches to conflict resolution. Mediation, negotiation and settlement of political disputes, London-New York.

\begin{abstract}
The purpose of the article is to show how the type of political system (authoritarian regime) influences the shape of regionalism in the Middle East and to what extent this political system
\end{abstract}


determines the features of cooperation between Arab states. To this end, a hypothesis was put forward according to which the authoritarian political system is a key obstacle to the successful integration and unification of the Middle East. Middle Eastern regionalism serves to protect and legitimize the political power of authoritarian leaders, whereas in Europe it guides to peace, stabilization and development. Authoritarian regionalism tends to reduce democratic ambitions and maintain the authoritarian status quo. In order to verify the hypothesis, the following research questions were posed. First, how is the type of political system related to successful integration? Second, can autocracies work effectively together? To verify the hypothesis and answer the research questions, the author referred to the theories of realism, constructivism, neo-functionalism and the typology of political systems to show that there is no single theory that could fully explain the processes in international relations. The conclusion of this article is that regional organizations created by authoritarian states are only symbolic and instrumental in nature and are oriented towards internal policy (the survival of the regime) rather than regional cooperation.

Keywords: regionalism, authoritarian regionalism, Middle East, integration, League of Arab States

\section{REGIONALIZM AUTORYTARNY NA BLISKIM WSCHODZIE}

\section{STRESZCZENIE}

Celem artykułu jest ukazanie, w jaki sposób typ systemu politycznego (reżim autorytarny) wpływa na kształt regionalizmu na Bliskim Wschodzie oraz w jakim stopniu ten system polityczny determinuje cechy współpracy między państwami arabskimi. Dla osiągnięcia tego celu postawiono hipotezę, zgodnie z którą autorytarny typ systemu politycznego stanowi kluczową przeszkodę w udanej integracji i zjednoczeniu Bliskiego Wschodu. Regionalizm bliskowschodni służy ochronie i legitymizacji władzy politycznej przywódców autorytarnych, podczas gdy regionalizm w Europie dąży do pokoju, stabilizacji i rozwoju. Regionalizm autorytarny dąży do zmniejszenia ambicji demokratycznych i utrzymania autorytarnego status quo. W celu weryfikacji hipotezy postawiono następujące pytania badawcze. Po pierwsze, w jaki sposób typ systemu politycznego jest związany z udaną integracją? Po drugie, czy autokracje mogą ze sobą skutecznie współpracować? Aby zweryfikować hipotezę i odpowiedzieć na pytania badawcze, autor odniósł się do teorii realizmu, konstruktywizmu, neofunkcjonalizmu i typologii systemów politycznych, pokazując jednocześnie, że nie ma jednej teorii, która mogłaby w pełni wyjaśnić procesy w stosunkach międzynarodowych. Konkluzja tego artykułu jest taka, że organizacje regionalne utworzone przez państwa autorytarne mają charakter wyłącznie symboliczny i instrumentalny i są zorientowane raczej na politykę wewnętrzną (przetrwanie reżimu) niż na współpracę regionalną.

Słowa kluczowe: regionalizm, regionalizm autorytarny, Bliski Wschód, integracja, Liga Państw Arabskich 
